\title{
The romance of Nahum Tate's King Lear
}

\author{
Katherine Romack \\ U niversity of West Florida, U S
}

\begin{abstract}
Nahum Tate's History of King Lear (1681) refigures Shakespeare's natural man on a Hobbesian model in order to make the play legible to Restoration audiences. As a way to mitigate Hobbes's ethically hollow conception of human nature as acquisitive and self-interested, Tate provides his viewers with a compensatory romance. Tate's "unaccommodated Man" is governed by self-interest yet capable of transcendent love (3.3.81). The liberties Tate took with Shakespeare catered to his audience's uneasy assimilation of secular and empirical ideas about what it meant to be human that made Shakespeare's original feel both alien and disturbing. The romanticized human nature offered up in Tate's Lear accounts for the success the play enjoyed well into the nineteenth century. As much as we might give the adaptation the side-eye, we are, in fact, affectively and ethically closer to Tate than we are to Shakespeare.
\end{abstract}

KEYWORDS: King Lear; Nahum Tate; Shakespeare; ethics; Christianity; romance.

\section{El romance del King Learde N ahum Tate*}

RESUMEN : La obra History of King Lear de Nahum Tate (1681) reinterpreta al hombre natural de Shakespeare de acuerdo a un modelo hobbesiano para hacer la obra más aceptable para el público de la Restauración. Para aliviar la concepción hobbesiana de la naturaleza humana como algo codicioso y egoísta, Tate le da a su público un romance compensatorio. El "unaccommodated Man" de Tate está gobernado por el egoísmo y sin embargo es capaz de sentir amor trascendente (3.3.81). Las libertades que Tate se toma con Shakespeare atienden a la asimilación incómoda, por parte de su público, de ideas seculares y empíricas acerca de

\section{0 romance de King Learde $\mathrm{N}$ ahum Tate}

RESUMO: History of King Lear (1681), de Nahum Tate, refaz o homem natural de Shakespeare segundo um modelo hobbesiano, a fim de deixar a peça mais ao gosto do público da Restauração. De maneira a polir a conceção de Hobbes da natureza humana como gananciosa e interessada apenas em si, Tate oferece aos seus espectadores um romance compensatório. O "unaccommodated Man" de Tate é governado pelo interesse próprio, mas é capaz de um amor transcendente (3.3.81). A licença que Tate adota em relação a Shakespeare ajusta-se à assimilação desconfortável que o seu público fez de ideias seculares e empíricas sobre o

*Translation into Spanish by Tamara Pérez-Fernández.

** Translation into Portuguese by Miguel Ramalhete.

(5) ederi 30 (2020): 91-115

https:/ / doi.org/ 10.34136/ sederi.2020.5 
lo que significa ser humano, y que hicieron que el original de Shakespeare fuese percibido como algo extraño e inquietante. La naturaleza humana romantizada que se presenta en el Lear de Tate explica el éxito del que disfrutó la obra hasta bien entrado el siglo XIX. Por mucho que menospreciemos la obra, nosotros estamos, de hecho, más alineados con Tate que con Shakespeare desde el punto de vista afectivo y ético.

PALABRAS CLAVE: King Lear; Nahum Tate; Shakespeare; ética; cristianismo; romance. que significa ser humano, eque fez o original de Shakespeare parecer estranho e perturbador. A natureza humana romantizada apresentada em Lear de Tate explica o sucesso que a peça teve até ao sé culo XIX. Por mais que possamos olhar de lado para esta adaptação, estamos, de facto, afetivamente e eticamente mais alinhados com Tate do que com Shakespeare.

PALAVRAS-CHAVE: King Lear; Nahum Tate; Shakespeare; ética; cristianismo; romance.

"This is simply dreadful," the modern reader might be inclined to react on first encountering Nahum Tate's The $\mathrm{H}$ istory of King Lear (1681). In what George Odell refers to as a "mangling" of the original, Tate transforms Shakespeare's tragedy into romance: Cordelia lives, and Lear is restored to his throne (1966, 54). ${ }^{1}$ An amorous entanglement between Cordelia and Edgar is added-along with a parental obstacle (Lear wants her to marry Burgundy). Tate softens the impact of Lear's response to Cordelia in the love trial, stressing that "the Infirmity of his Age" has "unfixed" his temperament, rendering him "Chol'ric" (1.1.55). Edgar assumes his disguise as Poor Tom to watch over Cordelia. Even the blinding of Gloucester is made meaningful (1.1.227). ${ }^{2}$ As Gloucester impeaches the cruelty of Cornwall, Regan, and Gonerill by revealing his blindness to the "pittying Crowd," the thought that his blindness has served the king's cause comforts him: "well have I sold my eyes, if the event prove happy for the injured King" (3.5.86; 4.2.12-13). Tate omits the Fool along with France (eliminating thethorny question of why an English

\footnotetext{
1 "Late eighteenth and early nineteenth-century critics could not have enough fun with the wind and the suns and the spheres that had nothing else to do but wait for Cordelia to ascend the throne" (Odell, 1966, 56).

${ }^{2}$ References to Tate's Lear are drawn from Sandra Clark's Shakespeare M ade Fit: Restoration Adaptations of Shakespeare (1997). I will use the Norton edition of Shakespeare's complete works edited by Stephen Greenblatt throughout, which provides both folio and quarto texts of Lear. Parentheticals with $\mathrm{F}$ or $\mathrm{Q}$ designate Shakespeare's Lear, those with no designation Tate's. For a summary of Tate's strategic use of both editions of Lear see Massai (2000). References to other plays and poems by Shakespeare will be drawn from the Greenblatt edition as well and cited by title in the parentheticals.
} 
King would provide a foreign power with a third of his kingdom). Tate's Bastard is a stock libertine rapist with an insatiable appetite for women, power, and luxury. ${ }^{3}$

What happened to society between Shakespeare and Tate to engender such a Lear? The liberties Tate took with Shakespeare catered to his audience's uneasy assimilation of secular and empirical ideas about what it meant to be human that rendered the Christian morality animating the original play obscure. This made Shakespeare's original feel both alien and disturbing to audiences and critics alike. Tate's conversion of Edmund into a Hobbesian libertine, his addition of a second love trial, and his elimination of the Fool all reflect a reformulation of the relationship between religion and the self, one that necessitates the elevation of amatory love to moral imperative. Tate's radically reconceived vision of "unaccommodated $M$ an" reflects the gradual seventeenth-century transformation of the human subject into an autonomous agent and an attendant transfer of moral authority from God to man (3.3.81). The ethical landscape of Tate's Lear is essentially Hobbesian. The Bastard, for example, is obviously a stock caricature of the vainglorious self-seeker, governed by desire for self-preservation and material increase. Tate also presents more nuanced exemplars of the rational mastery of the passions in the service of the common good. Characters like Cordelia and Edgar model this type of restraint. These characters reflect a broader cultural dissonance, torn, as they are, between passion and self interest in an environment where ethics is increasingly subjective and relativized. Tate resolves this conflict by converting Lear into romance. As much as we might find the romanticized Lear off-putting today, the twenty-first century is, in some crucial respects, more closely aligned with Tate than with Shakespeare.

\section{"The stars in secret influence comment"}

In 1985 William Elton published a famously salutary refutation of optimistic, Christian readings of Shakespeare's Lear. He was correct to assert that empirical evidence of Christian providentialism, redemption, and deliverance is nowhere to be found in Shakespeare's tragedy. Elton's claims about the "skeptical disintegration of

\footnotetext{
${ }^{3}$ For a discussion of the politics of rape in the play see Depledge (2014).
} 
providential belief" and the "breakdown of the medieval analogical relation" are, however, overstated $(1988,335)$. The hand of God is at work in the tragedy, even if it isn't always easy to detect. The stars, that "in secret influence comment" on the action of the play can only be regarded as indifferent from a modern epistemological perspective ("Sonnet 15," 4). Although it's true that the medieval idea of the corporate body was already coming under pressure, Shakespeare's audiences still had one foot in a medieval world that figured the creation as organically whole and unified by a Christian Logos. The self was still primarily regarded as planted by God into a landed or fixed order of things, and obedience to God and stewardship of the creation were still regarded as the chief social and ethical mandates. God is hidden, but nonetheless present in the uncannily sympathetic landscape that so evidently responds to Lear's internal turmoil. Numerous Christian references and images pepper the play-from Lear's initial ex nihilo nihil fit to the remarkable inversion of the Pietà at the close of the play. Every honest word and action in the play, especially Cordelia's "nothings" and Kent's service, are premised upon a devotion to the Christian God. Unfashionable as this claim might be, the play is deeply fideist. Perhaps it is, in part, our own distrust of logocentrism that prevents us from detecting the Christian impulses of the play.

For one thing, it hardly seems likely that a playwright seriously experimenting in agnostic skepticism would-to the horror of critics like Sidney, Jonson, and Puttenham-immediately turn his energies to the manifestly providential romance Pericles (ca. 1607-1608). Trevor Nunn, who directed an adaptation of the romance in 2016, draws the following comparison between Pericles and Lear:

At the end of many of Shakespeare's tragedies there is some sense
that a new order can begin. Attheend of Lear thereis no such feeling.
The Gods have been appealed to countless times, in countless awful
situations and in Lear they never hear, never respond. They never
makeanything better. It's almost astonishing that thenext thing that
he does is a play that has got a fairytale ingredient, a story that
culminates in the kinds of coincidence or luck that you can only
describeas miraculous. (Nunn 2016)

The proximate composition of the plays suggests that Pericles is something of a romantic restorative to Lear and, as such, essentially conservative. As Gower announces in the opening lines of Pericles, "The purchase [of the play is] to make men glorious, | Et bonum quo 
antiquas, eo melius" [the more ancient a good, the better] ("Chorus," 910). Pericles resounds with Marian imagery, Papist symbols, and Catholic rites. The play echoes both medieval hagiography and miracle plays about Mary Magdalene and Tobit (see Fel perin 2000). It is an especially interesting play to compare to Lear, not least because we have a rare piece of documentary evidence that reveals something of the religious reception of these plays in Shakespeare's England. In 1609 , a group of Catholic players, who had been performing under the authority of Sir Richard Chomley were charged before the Star Chamber with staging "a seditious play of Catholic purport, at York's house, Gowthwaite Hall in Nidderdale" (Sisson 1942, 135). Yet in addition to the miracle play about St. Christopher that led to the arrest of the company, the troupe's repertoire included both Pericles and King Lear (see Wood 2006, 441-50). That Shakespeare should follow Lear up with a romance bearing so striking a resemblance to a miracle play is, contra Nunn, unsurprising. ${ }^{4}$ Considering Lear alongside Pericles reveals an overarching generic pattern of suffering and redemption that is a residue of the collision between classical romance and the peregrinations of spiritual biography. As Marina Scordilis Brownlee writes of a thirteenth-century Spanish adaptation of the Latin romance of A polonius:

The antique matter of the original Apolonius biography has thus been radically transformed-serving an extra-textual truth in its Spanish reworking, the extra-textual truth of Christian doctrine. Fortune - the arbitrary, unjust force which tampers with human life in a thoroughly unpredictable manner-has been replaced by God, the arbiter of justice who rewards good and punishes evil accordingly. The multiple adventures - calculated only to provide suspenseful entertainment in the antique text-have acquired a transcendent meaning in the Spanish romance. $(1983,173)^{5}$

Lear's descent from king to wandering exile begins to look a lot more like a test of faith. Wemight wonder why Shakespeare chose to violate the tradition of romance and happy endings that dominate his medieval and Renaissance source texts. It may well be that

\footnotetext{
${ }^{4}$ In as much as Catholics and Protestants shared the same Christian history, the question of whether the play is Catholic or Protestant is immaterial to my argument here.

${ }^{5}$ For other investigations of the structural continuity between hagiography and dramatic romance see Deyermond (1975), Walsh (1977), Brownlee (1983), and Womack (1999).
} 
Shakespeare's tragic subversion of the story of Lear allowed him to interrogate the grounds of love and obligation in a way that the more romantic versions of the Lear story forestalled. ${ }^{6}$ The play is, after all, centrally concerned with putting love on trial.

The exchange between Edmund, Gloucester, and Edgar about the meaning of the eclipses in the second scene, presents us with a stark juxtaposition of the competing views of human nature presented by Shakespeare's play. Gloucester exhibits a belief in the metaphysical power of eclipses that "portend no good to us. Though the wisdom of nature can reason it thus and thus, yet nature finds itself scourged by the sequent effects" (F1.2.95-98). In response, Edmund labels him "credulous" (F1.2.156). The bastard exhibits a purely secular understanding of nature and therefore dismisses Gloucester's honest investment in astrological signs as "foolish."

This is the excellent foppery of the world: that when we are sick in fortune - often the surfeits of our own behavior-we make guilty of our disasters the sun, the moon, and the stars, as if we were villains by necessity, fools by heavenly compulsion, knaves, thieves, and treachers, by spherical predominance, drunkards, liars, and adulterers by an enforced obedience of planetary influence, and all that we are evil in, by a divine thrusting on. An admirable evasion of whoremaster man, to lay his goatish disposition to the charge of a star! (F1.2.108-15)

The thespian Edmund immediately dons the garb of a "sectary astronomical" in his subsequent interaction with Edgar. As his brother enters, Edmund quips, "and on's cue out he comes, like the catastrophe of the old comedy; mine is villainous melancholy, with a sigh like them of Bedlam. - $\mathrm{O}$, these eclipses do portend these divisions" (Q1.2.119-20). Edmund is a purely intellectual creature, relying on the human capacity for the utilization of instruments (in this instance, performance and rhetoric) to manipulate a world he conceives as a resource to be exploited. Yet, even as he mocks his father's belief in an astrological portent-one that is, of course,

\footnotetext{
${ }^{6}$ Shakespeare's most immediate source text, the anonymous True Chronicle $\mathrm{H}$ istory of King Leir (1594), for example, was deeply ideological, deploying pastoral romance didactically to generate support for Elizabeth's foreign policy: "Spectators (and Elizabeth) were offered an idyllic and optimistic view of the conflict, while the menacing figure of a foreign invader was turned into a chivalric hero only willing to save his beloved's father from utter ruin. The succession issue is not even mentioned, and the foreign monarch soon returns to his kingdom" (Álvarez-Recio 2012, 664).
} 
resoundingly vindicated by the play's action-he unwittingly reveals that the genesis of his own villainy was wrought by "a divine thrusting on":

My father compounded with my mother under the Dragon's tail and my nativity was under Ursa Major, so that it follows I am rough and lecherous. Fut! I should have been that I am had the mai denliest star in the firmament twinkled on my bastardy. (F1.2.116-21)

In 1946, Johnstone Parr observed that, having been born under the sign of Ursa Major, "Edmund's career shows him to be in large measure the living embodiment of astral influences exerted by the malignant constellation" (Parr 1946, 183). A sign governed by the conjunction of Mars and Venus, Ursa Major portended depravity, deception, cruelty, fornication, adultery, incest-the very "machinations, hollowness, treachery, and all ruinous disorders" Gloucester attributes to the eclipses (F1.2.103-104). These qualities are identical to the "rough and lecherous" constitution Edmund denies even as he cannot escape it (F1.2.101-103). Edmund is damned, incapable of transforming his erotic and political cupidity into caritas. As he lies dying, he makes a final effort to contravene this nature: "Some good I mean to do, I Despite of mine own nature" (F5.3.21819). Yet even this attempt to escape the moral disposition thrust upon him is destined to fail.

Tate foregrounds the Bastard's "Thou Nature" soliloquy, placing it at the opening of the first act. This deflects attention from Lear's love trial and foregrounds Edmund's transformation from a Machiavel to a Hobbesian villain. Tate cuts all mention of Edmund's nativity, and with it, anything that establishes his evil as unfree or Satanically "thrust on." The Bastard is "cynical, treacherous, lustful and cruel, judging the rightness of a cause by its success, and recognizing no power beyond his own strength" (Black 1967b, 380). He is a self-styled libertine, a conspicuous consumer and dissipated lover of opulence, a creature of self-interest pitting his craftiness against the "right of Law," the only obstacle to the unconstrained pursuit of desire in the world Tate creates (1.1.12-13). Edmund's evil is neither intrinsic nor metaphysical, it is volitional-he chooses self-interest over the common good, and this choice is marked as depraved. His libidinous desire for possession is boundless. In Shakespeare, Edmund is also driven by eros, but this is understood in the Renaissance sense, as the fallen product of an original sin that, at best, inspired a longing for 
God and, at worst, became idolatrously fixated on temporal objects of desire. Critics frequently remark that Shakespeare's Edmund is Hobbesean. This is, of course, an anachronism. The central difference between Edmund and Tate's Bastard is that eros in the Restoration was coming to be understood as natural, inevitable, and morally neutral. This subtle shift in emphasis had titanic ethical implications. As eros is transformed into a valueneutral passion, there is no impetus to sublimate desire from self-interest to a more ethically acceptable form.

The ontology governing Shakespeare's Lear declined in direct proportion to the rise of Hobbesian nominalism and a mechanical and reified post-Cartesian view of the self. Human sense perception was itself radically altered. New gods supplanted the old. Tate wrote on the cusp of the Deist revolution that would reject the superstitions of both revealed religion and church dogma in favor of an outlook in which God's laws are reformulated as intrinsic to nature and rationally discernable. This God is the D eus A bsconditus that Elton misattributes to Shakespeare's L ear. ${ }^{7}$ As Simon May remarks, "It took the genius of Baruch Spinoza to place man so indissolubly in nature that the very idea of transcending it [...] would make no sense" (May 2011,143 ). Ideas of good and evil persist, but they are less fixed and universal and more relative and contingent, a matter of customary agreement, held together by law, and invested with a telos by a remote, though rationally demonstrable, Creator. The human subject that had traditionally understood itself as existing in a metonymic relation to the order of things surrendered to thereign of thesovereign subject. ${ }^{8}$ The modern subject is free and active, exercising subjective dominion over a reified world by rationally weighing the probability of empirical outcomes. This subject interprets the world through the

\footnotetext{
${ }^{7}$ The contributions to this idea of God available to Tate, beyond Hobbes's, include Herbert's D e veritate (first published in England in 1633) and D e religions (1645) as well as Spinoza's Tractatus theologico-politicus (1670). Charles Blount's Anima mundi (1679), G reat is D iana of the Ephesians (1680), and The T wo First Books of Philostratus (1680) were all published in the years immediately preceding the appearance of Tate's Lear.

${ }^{8}$ This subject is "the free, unconstrained author of meaning and action, the origin of history. Unified, knowing, and autonomous, the human being seeks a political system which guarantees freedom of choice. Western liberal democracy, freely chosen, and thus evidently the unconstrained expression of human nature, was born in the seventeenth century with the emergence of the individual and the victory of constitutionalism in the consecutive English revolutions of the 1640s and 1688" (Belsey 1985, 8).
} 
lens of the cost-benefit analysis required to navigate a landscape of competing interests. There is an intensified need to scrutinize the self and others for evidence of motivation. The complex choreography of manners that emerges in this period is only one product of an intensified need to scrutinize the self and others. As N orbert Elias has it, 'In order to be 'courteous' by the standard of civilité, one is to some extent obliged to observe, to look about oneself and pay attention to people and their motives" $(1978,78)$. The ethical constitution or "credit" of the subject could presumably be identified by a careful observation of patterns of social conduct. This emphasis on behavioral observation goes hand-in-hand with the period's widespread fascination with probability.

Tate took A ristotle's dictum about dramatic probability seriously. ${ }^{9}$ He eliminates the loose ends and ambiguities of Shakespeare's play with a surgical precision that renders the action credible and divests the play of its sublime mystery. ${ }^{10}$ Tate's idea of the probable was, unlike Aristotle's or Shakespeare's, conditioned by the idea of the rational calculus. ${ }^{11}$ Mathematical models of probability held out the promise of revealing the mechanics of the natural world, and these were accompanied by new quantitative and utilitarian models of social and moral probability. Tate's Bastard is evil because he is an untrustworthy cheat who refuses to subordinate his immediate selfinterest to the rules of consent that preserve the common good. What this "good" might consist of, however, is rather amorphous and difficult to pin down. The Bastard's evil, his turn away from the laws

\footnotetext{
9 "A poet's object is not to tell what actually happened but what could and would happen either probably or inevitably" (A ristotle, 35 [1451a.36-38]).

10 "Why does Edgar adopt such an uncomfortablealias instead of simply running away? why do both heand Kent retain their disguises after the need for them has passed? why are Lear and Gloucester left straying about rather than being delivered to the French camp? what happens to the fool? who is in command of the French army? Tate's reforms answer or abolish almost all of these questions, and so recover the dramatis personae as active subjects within a syntax of intelligible cause and effect" (Womack 2002, 99).

${ }^{11}$ It is no coincidence that the period that favored Tate's Lear at the expense of Shakespeare's corresponds exactly to the period Lorraine Daston and others have identified with the evolution of Classical probability theory into a reasonable calculus. "Between Roughly 1650 and 1840 mathematicians of the caliber of Blaise Pascal, Jacob Bernoulli, and Pierre Simon Laplace labored over a model of rational decision, action and belief under conditions of uncertainty. Almost all of the problems they addressed were couched in these terms" (Daston 1998, xi). See also Patay (1984).
} 
of the social contract, is marked as an unnatural volition. As he announces, twelvelines in, "Of law I will oppose a bastard's cunning" (1.1.12). Significantly, Shakespeare's Edmund makes no specific reference to law, as the informal communal idea of the Christian bond had not yet been supplanted by the legislative and contractual enforcement of social responsibility. In Shakespeare's age, social relations, even in the marketplace, were still "conceived of in explicitly moral terms, and not those of amoral self-interest" (Muldrew 1993, 177). As the seventeenth century wore on, debt litigation exploded with the erosion of the communitarian Christian ethics that had once guaranteed early modern credit. ${ }^{12}$ Especially distressing to the Restoration subject is the possibility that the laws of nature, and of the market, cannot be unlocked and harnessed by reason, and that the world is essentially amoral, chaotic and meaningless. This universe is the one that critics, from the Restoration on, have erroneously assigned to Shakespeare's Lear. Tate's return to romance attempts to rectify the perceived moral vacuity of Shakespeare's original.

\section{"There's beggary in the love that can be reckoned"}

Describing the royalist romance of the 1650s, Victoria Kahn explains that it depicts "a world of passion and interest" where "honor" and "nobility" serve as a thin veil for "factional self-interest and selfaggrandizement" $(2002,627){ }^{13}$ The writers of the new romance

\footnotetext{
${ }^{12} \mathrm{~N}$ or were people, Muldrew continues, "in any way concerned with interpreting profit as a social good likely to lead to increased future wealth, in the manner of utilitarian ethics" $(1993,177)$.

${ }^{13}$ Christine Lee provides an excellent survey of the problems that inhere in the critical deployment of the term "romance." "Much of what we today call Renaissance 'romance' was, in its own day, a genre without a name-if, in fact, the authors of the new modes of fiction believed they worked with a common genre at all" $(2014,287)$. Like Lee, I am interested in the way that the formalization of "romance" in the 1620s and 30s shifts the generic emphasis of the term from "male heroics," chivalric wandering, and the miraculous to "imagination and the passions" restrained by neoclassical unity and new understandings of probability $(2014,299)$. I am also, like James Grantham Turner, less interested in the way that romance contributed to the rise of the novel than I am in the distinction al ready being drawn in the restoration between the Old Romance and New Romance that is captured perfectly in Turner's epigraph drawn from Pierre-Daniel Huett's 1672 Treatise of Romances: “As our Manners and Peopleare refin'd, Romances also hold pace with us, and by the same degrees arrive to perfection. Giants, Dragons and Enchanted Castles, which made so much noise in
} 
regarded the rational control of self-interest and the restraint of the passions as essential to cultural stability. Yet, they also "resist the complete demystification of the passions - the reduction of the passions to varieties of self-interest" (Kahn 2002, 627). Passionatelove, in particular, becomes synonymous with virtue. In the Restoration and eighteenth century, the deferred and ennobling object of the romantic quest is progressively restricted to the object of amorous love. ${ }^{14}$ The relative moral poverty of virtues such as honor and nobility in the new romance is bound up with the domestication of the romantic object. By the beginning of the twentieth century, romance would become even more strictly conflated with amorous love. Tate regarded his greatest improvement of Shakespeare to be the insertion of a "Love betwixt Edgar and Cordelia," characterizing this as an "Expedient to rectifie what was wanting in the Regularity and Probability of the Tale" ("Dedication"). This "Expedient" makes credible Cordelia's refusal to provide words of love to Lear and explains the intensity of his response to this withholding. It also gives "Countenance to Edgar's Disguise, making that a generous Design that was before a poor Shift to save his Life" and heightens "The Distress of the Story" ("Dedication"). Lear's love trial in Tate is prefaced by an exchange between Edgar and Cordelia in which they lament Cordelia's impending betrothal to Burgundy:

EDGAR Cordelia, royal Fair, turn yet once more,

And e're successfull Burgundy receive

The treasure of thy Beauties from the King,

E're happy Burgundy for ever fold Thee,

Cast back one pitying Look on wretched Edgar.

CORDELIA Alas what wou'd the wretched Edgar with

The more Unfortunate Cordelia;

Who in obedience to a Father's will

Flys from her Edgar's Arms to Burgundy's? (1.1.56-64)

This exchange conditions the meaning of the love trial to come (which Tate lifts almost verbatim from the original). Cordelia's

Romances of former times, are now no longer heard of" (Turner 2012, 58). Complicating this is the fact that theatrical romance has a history distinct from that of poetry or prose.

${ }^{14}$ Patricia Parker characterizes romance as "a form that simultaneously quests for and postpones a particular end, objective, or object" $(1979,4)$. Barbara Fuchs, following Parker, reads romance as a "textual strategy" rather than a collection of generic markers $(2004,9)$. 
communication of an incalculable love, duty, and obligation invested with metaphysical and traditional import is reduced to bargaining and rhetorical maneuvering. Tate's stress is on Cordelia's revulsion at the thought of the "loath'd Embraces" of Burgundy (1.1.95). In the lines that follow, Lear's response is made probable in two ways. His choleric disposition is attributable to age, and he is predictably outraged that Cordelia's fondness for the "Rebel Edgar" has sparked her dissent.

LEAR And goes thy Heart with this?

'Tis said that I am Chol'rick, judge me Gods, Is there not cause? now Minion I perceive

The Truth of what has been suggested to Us, Thy Fondness for the Rebel Son of G loster, False to his Father, as Thou art to my Hopes. (1.1.16-121)

Most modern interpretations of Lear share Tate's investment in Cordelia's motives and intentions. In 1811, Coleridge attributed her refusal to produce a love boast to "some little faulty admixture of pride and sullenness," while W.W. Lloyd characterized Cordelia as "provoking" the tragic outcome of the play by "mistaking the point of moral support where service was most wanted" (Coleridge 1874, 192; Lloyd 1889, 444-45). Shellee Hendricks attributes to Cordelia an incestuous "resistance to exogamy, a resistance which implies a desire to remain in part with King Lear" $(1999,52)$. William Dodd more positively evaluates Cordelia as "a character struggling to possess her dialogic right of access to the world of personhood" (1999, 490). Richard Halpern represents Cordelia as a creature motivated by the intrigues of court. He asserts that she "has more than a little in common with the play's villainous characters," representing her response to her father as calculated, even "cruel" (1991, 248-49). In Halpern's reading, Cordelia "poses a fundamental challenge to [Lear's] authority" and in so doing "releases an aristocratic game of challenge and counter challenge" (1991, 249-50). ${ }^{15}$

The subjective agency that motivates Cordelia in Tate cannot be assumed of Shakespeare's heroine. Autonomy and its derivative discourses of right, the goodness of freedom, self-sufficiency, and selfgovernance do not pertain to a culture in which all are subject.

15 These are only a few examples that are close-to-hand as a comprehensive enumeration would be impossible. One would be hard put to find a critical appraisal of Cordelia that isn't organized around the question of her volition. 
Cordelia's silences in the original do not conceal hidden motives in need of excavation or reveal a naively conceived and abstract "impotent goodness" (Halpern 1991, 248). In the love-trial, Shakespeare dramatizes the force of the qualitative bonds governed by Christian obligation. Cordelia's expression of duty is meaningful only with reference to a subjectivity understood as metonymically related to a corporate unity authored by and subject to God.

CORDELIA Good my lord,

You have begot me, bred me, loved me.

I return those duties back as are right fit-

Obey you, love you, and most honour you.

Why have my sisters husbands if they say

They love you all? Haply, when I shall wed

That lord whose hand must take my plight shall carry

Half my love with him, half my care and duty.

Sure, I shall never marry like my sisters,

To love my father all. (Q1.84-93)

Cordelia's duty is unintelligible outside a context that binds social obligation to obedience. For instance, it is incomprehensible to the transactional attitude to others and the world that is demanded by the economy of primitive accumulation. Lear's tragic flaw is that he fails to understand that love is not a quantity to be accumulated, that "there's beggary in the love that can be reckon'd" (Antony and Cleopatra, 1.1.15). When Cordelia gives half her love away, this will in no way diminish her lovefor her father, for unlike exchange-value her love is unquantifiable. Terence Hawkes has noted that Shakespeare's love test draws on a longstanding pun on two senses of love dating back to the fourteenth and fifteenth centuries, when the Old English lofian (to appraise, value, or state the price of) and lufian (to love) became homonyms. The pun is found in both Wace and Holinshed (Hawkes 1959, 178). Cordelia's "nothings" express her lufian, her faith in the unquantifiableidea of the Christian bond. This idea of the bond was the glue of an economy of informal reciprocal obligation that predated modern credit and contract, and that structured nearly every aspect of social life in the early modern period (see Muldrew 1993, 2001). This idea of obligation was steadily eroded by the selffashioning and desacralized ionotropic displays of secular power that characterized the Elizabethan and Jacobean courts (see Rust 2006). James I's totalizing form of absolutism, which eliminated entirely "the reciprocal duties of dominus and homo," is clearly an important target 
of Shakespeare's play (quoted in Halpern 1991, 220). Like James I, Lear is oblivious to the reciprocity and stewardship informing the Christian bond-they both reduce kingship to a one-sided property relation (1991, 221-23).

Shakespeare regularly wrote of the inadequacy of words to praise the beloved, and commonly presented the poet as a debtor incapable of paying the usurer. Hesimilarly al ways grants genetic reproduction an intrinsic value that poetic production is incapable of capturing. Cordelia's "Love" is a sublime "nothing," inaudible to a father invested in "reckoning" her love. As Hawkes elaborates, "Cordelia's refusal of his world of quantity and calculation had been met by Lear's exasperated parody of theological debate, 'Nothing will come of nothing: speak again.' But human beings never simply 'speak'. Any utterance is always complicated, particularly in a pre-literate society, by the body" (1959, 52). The body's "unignorable presence supplies a living and modifying context" for the nothings spoken by Cordelia (1959, 52). Lear's investment in words of love at the play's opening gives way to an ability to hear the nothings of his poor, hanged fool at the end: "Cordelia, Cordelia: stay a little | Ha? What is't thou sayst? Her voice was ever soft" (F.5.3.246). His final words in the Folio edition suggest that at the moment of his death he sees his daughter's lips parting to speak: “Do you see this? Look on her. Look, Her lips. Look there, look there" (F5.3.285-86). In the quarto edition, this rapprochement is followed by Kent's final words, "I have a journey, sir, shortly to go: | My master calls, and I must not say no" (Q24. 31516).

Love in Shakespeare was still evaluated in terms of its relationship to a transcendent God or fallen temporality. When desire works as a motor for transcendence it is redemptive; when it is idolatrous it is Satanic. In contrast, Restoration literature placed an increased premium on a temporal love that muddies the ethics of affect. Not only did erotic love change from "a potentially tragic to potentially desirable condition," with the rise of such things as companionate marriage, it was well on its way to "achieving what once only divine lovewas thought capable of: to be our ultimate source of meaning and happiness, and of power over suffering and disappointment" (Gorer 1989, 8; May 2011, 1). The royally-sponsored theatre is peopled by characters who openly embrace self-interest while aspiring to the interiority and sincerity of the modern individual. The concealment of 
the self-interest that pervades Restoration amatory discourse is a slippery endeavor that can only be accomplished through an abstraction or, rather a de-referentialization of love's object. Tate's restoration reduction of Cordelia to a woman wrangling to get her man occurs at the same historical moment that freethinking, sincerity, and interiority were being assigned to individual subjects.

Tate's Hobbesian romance exemplifies this transvaluation of eros. Hobbes understood all human behavior to be a product of a perpetual war between self-preservation and power adjudicated by reason. However, reason for Hobbes was not, as it had been for Descartes, conceived of as immaterial substance emanating from a mind conceived of as synonymous with the soul. Instead, "The very rationality of the calculus is defined by the capacity of the passion to guide the imagination and identify the means for reaching the desired objective" (Coli 2006, 75). Reason is refigured "as a system of signs, logical operations, laws and conventions" that are purely immanentthe product of the movement generated by the conflict between warring passions (Coli 2006, 80). The problem with Hobbes's social contract is that there is no eternal guarantee of allegiance to it, nothing to ensure that the impulses generated by individual memories of fear and pain would be enough to hold in check the pleasurable will to power that always threatens to tear the community apart. A stronger incentivization of fealty to the social contract-a "new affective basis for political obligation"-was needed (Kahn 2002, 627). ${ }^{16}$

Love, in Tate's Lear, cements the social order. This love, however, is qualitatively different from the eros, agape, and philia of the Renaissance. It is simultaneously secular and transcendent-either "true" (because free and untainted by interest) or non-existent. After Burgundy rejects Cordelia, she proceeds to throw Edgar into confusion by pretending to reject his love. In thelovetrial orchestrated by Cordelia, passionate love must be certified as untainted by "Int'rest." Edgar must prove his disinterested sincerity before she will grant him her love:

This Baseness of th' ignoble Burgundy

Draws just suspicion on the Race of Men,

${ }^{16}$ The general attempt to navigate the antipodal secular relationship between rational constraint and passion would be formalized seventy years later with Baumgarten's aesthetics. 
His Love was Int'rest, so may E dgar's be

And He but with more Complement dissemble;

If so, I shall oblige him by Denying:

But if his Love be fixt, such Constant flame

As warms our Breasts, if such I find his Passion,

My Heart as gratefull to his Truth shall be,

And Cold Cordelia prove as Kind as He. (1.1.227-33)

Edgar's love must remain disinterested if it is to be freely chosen. Cordelia's faith in the bright flame of freely-chosen romantic love invests it with a spiritual quality capable of suturing over the illogic of figuring disinterested interest as an ethical good.

\section{"This great stage of fools"}

One of the most important revelations about human nature in Shakespeare's Lear is that it is essentially foolish: "When we are born, we cry that we are come | To this great stage of fools" (F4.5.172-73). Fools represent the messiness and ambiguity of the human condition, all of the contradictory attributes of human experience that defy rational explanation and sometimes touch the transcendent. The Fool's resistance to categorical determination is grounded in his liminal, unpropertied status. The Fool, the wandering Lear, and Poor Tom are all creatures who have relinquished their possessions, down to their very self-possession. The progress from identity to liminality requires a complete divestiture of the self and its interests. The deployments of the term "slave" in Lear are interesting in this regard, as they so frequently align slavery not with a lack of self-possession, but with violations of Christian obligation. Oswald is, for example, repeatedly labeled a slave by honest Kent because "Such smiling rogues as these, | Like rats, oft bite the holy cords a-twain | Which are too intrinse t'unloose" (F2.2.67-68). Kent, by contrast, has "ever honour'd [Lear] as my king, I Loved as my father, as my master follow'd, | As my great patron thought on in my prayers" (F1.1.13840). Kent's love of Lear is grounded in a positive ethos of obedience and subjection.

Shakespeare's play was written during the Union Controversy, and James's selective use of feudal precedent to promote a species of absolutism that foregrounded feudal property law and downplayed theological justifications for monarchical power-in effect, converting the power of kingship "from a political into a property relation" (1991, 
221). The landscape of Shakespeare's Lear is thoroughly absolutist on a Stuart model. Lear comes to understand that reducing monarchy to property alone renders it vulnerable. "Lear carves up his patrimony in one bold if misguided stroke, whereas James fritters his away through conspicuous consumption and the inflation of honors," but the result is much the same (231). Lear's abdication initiates the reduction of "an armigerous nobility into a class welding only consumption signs" (242). ${ }^{17}$ Once Lear gives his property away, his authority evaporates. However, this detachment from property grants him (and Edgar, who experiences a similar dispossession) a special access to the metaphysical space occupied by the Fool. To be foolish is to embrace the mysterious inscrutability of human existence.

The Fool is the paragon of unaccommodated man. A figure of paradox and irresolvable contradiction, theFool in Lear is worldly but innocent, young but wise, facile but profound-even male but female. ${ }^{18}$ As we have seen, there is no place for superstitious fools like Gloucester in the self-interested economy of human naturelaid out by Tate. The many references to fools and foolishness that pepper Shakespeare's original (more than 120 altogether) are reduced by Tate to seven. The Fool is simply eradicated from the play, resulting in a Lear whose madness is transformed from a profound philosophical interrogation of the ground of value, truth, and ethics to the solipsistic sickness and infirmity of an increasingly self-interested culture. What Shakespeare depicted as Lear's de-centering through a dispossession that occasions an encounter with the unnamable, is, for Tate, simply a question of mental illness, a "real" versus "pretended" madness

\footnotetext{
${ }^{17}$ One thing that is surprising about Tate's adaptation is just how little it addresses the political content of Shakespeare's play. His play was published in the midst of the Exclusion Crisis yet expresses very littleinterest in engaging the politics of the day. This probably had something to do with the reception of his Richard II. But it was also because signs of kingship in Tate's day had al ready been thoroughly voided of spiritual substance. For examinations of the adaptation that situate Tate's Lear within the Exclusion Crisis, seeHardman (2000), Depledge(2014) and Bender (2016). Other studies of the influence of the Exclusion Crisis on Tate include Wikander (1986), Viator (1988), Johnson (1995), and Álvarez-Recio (2009).

${ }^{18}$ There is a rising critical consensus that the close association between the characters of Cordelia and the Fool was physically accentuated on the stage by the same youthful actor playing each of these characters. See A brams (1985) and Green (1972). For other appraisals of the fool in Lear see Empson (1949), Goldsmith (1955), Strong (1961), and Seiden (1979).
} 
("Dedication"). ${ }^{19}$ Lear is, from the opening of Tate's play, "with wild starts of passion hourly seiz'd" (1.1.51-55). His madness is, in a word, pathological-he is marked as feeble and mentally unstable from the beginning. If Tatedraws a sharp distinction between Lear's "real" and the king's "pretended" madness, Shakespeare elides them in the figure of Edgar who does go out of his head as he relinquishes everything, including his noble name, becoming, apart from the fool, the least "accommodated" of any character in Lear: "Edgar I nothing am" (F2.2.178). It is divestiture that brings Lear closest to the truth of the human condition-that we possess nothing, not even ourselves: "Behold, the heaven and the heaven of heavens is the Lord's thy God, the earth also, with all that therein is" (Deuteronomy 10:14). We are not the owners but the stewards of creation. It is at this moment of recognition that Lear labels Poor Tom a "noble Philosopher" and asks for his companionship (4.4.154), evoking the philia at the heart of philosophy's central existential question. As Sylviane Agacinski observes in "La question de l'autre," the possibility of asking the question of being is al ready bound up with an obligation to others. "If the philosophical question is a shared one, philosophy must already be home to a certain P hilia" (54). It was something likethis conjunction of being with a love grounded in dispossession that Shakespeare had in mind when composing Lear.

\section{The Tatefied Lear}

The cadre of editors and theatre critics that proliferated in the Restoration almost universally took issue with Shakespeare's killing of Cordelia (as well as with the insinuation that Kent would follow Lear to the grave). In his "Remarks on the Plays of Shakespeare" (1710), Charles Gildon expressed a strong preference for Tate's Lear, asserting that the destruction of Cordelia and Kent in Shakespeare's original was so random and unjust that it rendered its audiences too disgusted to achieve the level of "pity and fear" that would allow them to experience the play as tragedy (Gildon 1710, 406). A year later

\footnotetext{
${ }^{19}$ What, Shakespeare seems to ask, is the relationship between the diverse, messy, and transient world of human experience and the transcendent but objective good that grants meaning to this inchoate experience? As it is impossibleto verbally articulate the force animating Christian love, Lear seems to ask: might not the metaphysical nature of obligation be better approached through the performative experience?
} 
Joseph Addison, one of the few holdouts for Shakespeare, protested that the play "lost half its Beauty" when it was forced to conform to this "chymerical Notion of Poetical Justice" $(1739,156)$. As chimerical as many of the critical charges laid against Shakespeare's Lear might have been (the notoriously erratic critical appeals to the dramatic unities are a case in point) Tate's play prevailed. With the exception of occasional purists like Addison, audiences and critics alike found themselves applauding Tate's thoroughgoing "rectification of Lear" ("Dedication"). Even Samuel Johnson added his "general suffrage" to the new Lear-although he grudgingly concurred with Addison that the original was "deservedly celebrated among the dramas of Shakespeare" $(1765,158)$. Johnson believed that the play's ostensible lack of moral probability (the chief criticism of Shakespeare's play from the Restoration on) was a result of "the barbarity and ignorance of the age to which this story is referred" $(1765,158)$. Behind the slew of vague and inchoate seventeenth and eighteenth-century denunciations of Shakespeare's Lear, what the critics are actually conveying is that Shakespeare's supposed elision of the transcendent laws governing man's existence in the tragedy evoked in them the same species of dread that seized Pascal when he contemplated the possibility of eternal silence. ${ }^{20}$ Johnson characterized the play as "unendurable" because the Christian ethics assumed by Shakespeare's Lear were no longer operative (171-72). Such discomfort with Lear could only appear in a culture that had lost the ability to intuit the divine authority suffusing theinscrutablenothings of Shakespeare's play.

Tate himself characterized Shakespeare's play as primitive, "a heap of jewels, unstrung and unpolished" ("Dedication"). ${ }^{21}$ He felt no compunction about bringing Shakespeare up to date and into line with the taste of Restoration audiences, pillaging Shakespeare's play

\footnotetext{
20 "When I consider the short duration of my life, swallowed up in the eternity before and after, the little space which I fill, and even can see, engulfed in the infinite immensity of spaces of which I am ignorant, and which know me not, I am frightened, and am astonished at being here rather than there; for there is no reason why hererather than there, why now rather than then. Who has put me here? By whose order and direction have this place and time been al lotted to me? [...] The eternal silence of these infinite spaces frightens me" (Pascal 1958, 61).

${ }^{21}$ Labeling Shakespeare "unpolished" was, importantly, not a mistake made by Johnson, who therefore found Shakespeare's play all the more disturbing, even, as Frank Kermode puts it, "wounding" $(2005,171)$.
} 
without any misgivings about "so bold a Change" ("Dedication"). What Tate could only describe as a chaotic assemblage of "extravagant Nature (I know not how else to express it)" required him to take the "heap" that was Shakespeare's Lear and polish it into a form that a Restoration audience would find natural and appealing ("Dedication"). This refinement required an aesthetic reformulation of human nature, as Shakespeare had presented it, and a liberation of the unfree subject that constituted Shakespeare's idea of "unaccommodated man." He wagered that making everything in the play plausible to his audiences by presenting characters and outcomes that spectators could find believable would guarantee its success.

And so it did. The Tatefied Lear would dominate the stage at the expense of Shakespeare's well into the nineteenth century. Borrowings from Tate, in fact, continue to render performances of the play more palatable today. ${ }^{22}$ By the time Tate adapted the play sometime around 1681, the "poor, bare, forked, animal" contemplated in Shakespeare's Lear became, for most, less legibleand, consequently, more troubling (F3.4.96-97). Tate was no philosopher: he was a playwright, and his only concern was that the play be "well Receiv'd by my Audience" ("Dedication"). He steered a wide course around the hard existential questions posed by the tragedy- his focus was on the here and now of this world. The neoclassical reformation of the theatre and its reformed romance appealed to a spectator who was no longer

prepared to take therisks of terror and revelation implicit in tragedy. He wished to shudder briefly or dream at ease. When coming from thestreet into the playhouse, hewas not leaving thereal for the more real (as does any man who is willing to encounter the imaginings of Aeschylus, Shakespeare or Racine); he was moving from the fierce

\footnotetext{
22 The process of returning Shakespeare's original to the stage can be seen as early as Garrick's 1756 production which restored much of the original language to the play but left Tate's innovations with plot intact. In the period between Garrick and Macready's thoroughgoing return of Shakespeare's Lear to the stage in 1838, Tate's version continued to dominate the stage. For extended discussions of the adaptation history of Lear see Spencer (1963), and Black (1967a). For an account of the myriad ways in which Tate's adaptation continues to shape contemporary productions of Lear, see Adler (1985).
} 
solicitations of current history and economic purpose into therepose of illusion. (Steiner 1968, 116) ${ }^{23}$

The culture to which Tate's play appealed was one that Pascal violently denounced:

we condemn those who live without thought of the ultimate end of life, who let themsel ves beguided by their own inclinations and their own pleasures without reflection and without concern, and, as if they could annihilate eternity by turning away their thought from it, think only of making themselves happy for the moment. (Pascal 1958, 59)

We are more attracted to than disturbed by what remains of Shakespeare's original, perhaps, because the nihilism dreaded by Tate's audience has become second nature to us. What we find most aesthetically unappetizing about Tate's Lear is the play's romantic innovations; yet, our current reverence for Lear, as well as our distaste for the conservative amatory economy of Tate's adaptation, are each premised upon a refusal to acknowledge the timeworn ethical system that governed Shakespeare's tragedy. Our investment in the moral neutrality of the passions, in fact, goes far beyond Tate's. Instead of converting amorous love into a virtue, we posit choice itself as an unquestionable good. As much as we might try to rationalize our own instinctive subjective volunteerism, it is quite incompatible with any ethical schema. Tate, at least, can be credited with attempting to supply Lear with an ethics.

\section{References}

A brams, Richard. 1985. "The Double Casting of Cordelia and the King's Fool:

A Theatrical View." Texas Studies in Literature and Language 27 (4): 354-68.

Addison, Joseph, and Richard Steele. 1739. The Spectator. $12^{\text {th }}$ ed. London: Printed for J. and R. Tonson and S. Draper.

Adler, Doris. 1985. “The Half-Life of Tate in King Lear." The Kenyon Review 7 (3): 52-56.

${ }^{23}$ Renaissanceaudiences "delighted in clowns, in comic interludes, and in theacrobatics and brutality of physical action. The Elizabethan spectator had strong nerves and demanded that they be played upon" (Steiner 1968, 21). This is just the sort of thing that Tate excises from his adaptation. 
Agacinski, Sylviane. 2004. "The Question of the Other (Critique of Egocentrism)." In French Women Philosophers, A Contemporary Reader, edited by Christina Howells, 39-55. London: Routledge.

Álvarez-Recio, Leticia. 2009. “Nahum Tate's The History of King Richard the Second (1681): Politics and Censorship during the Exclusion Crisis." Restoration and Eighteenth-Century Theatre Research 24 (1): 17-30.

Álvarez-Recio, Leticia. 2012. "Romance, Politics and Money: The French Cause in The TrueChronicleH istory of King Leir." English Studies 93 (6): 65267.

A ristotle. 1932. A ristotle: The Poetics. Longinus: On the Sublime. Demetrius: On Style. Edited by W. Hamilton Fyfe. London: W. Heinemann.

Belsey, Catherine. 1985. The Subject of Tragedy: Identity and Difference in Renaissance D rama. London: Methuen.

Bender, Ashley. 2016. "Rhetorical Bodies in Nahum Tate's King Lear and Ingratitude of a Commonw ealth." Papers on Language and Literature 52 (1): 6390.

Black, James. 1967a. "A n Augustan Stage History: Nahum Tate's King Lear." Restoration and $18^{\text {th }}$ Century Theatre Research 6 (1): 36-54.

Black, James. 1967b. "The Influence of Hobbes on Nahum Tate's King Lear." Studies in English Literature 7 (3): 377-85.

Blount, Charles. 1679. A nima mundi, or, An historical narration of the opinions of the ancients concerning man's soul after this life according to unenlight[e]ned nature. London: Printed by Will. Cademan.

Blount, Charles. 1680a. Great is D iana of the Ephesians, or, The original of idolatry together with the politick institution of the gentiles sacrifices. London.

Blount, Charles. 1680b. The T wo First Books of Philostratus concerning the L ife of A pollonius Tyaneus written originally in Greek, and now published in English: together with philological notes upon each chapter. London: Printed for Nathaniel Thompson.

Brownlee, Marina Scordilis. 1983. "Writing and Scripture in the Libro De A pol onio: The Conflation of Hagiography and Romance." H ispanic R eview 51 (2): 159-74.

Coleridge, Samuel Taylor. 1874. Shakespeare, Ben Jonson, Beaumont and Fletcher: $\mathrm{N}$ otes and Lectures. Edited by Edward Howell. Liverpool: Edward Howell.

Coli, Daniela. 2006. “Hobbes's Revolution." In Politics and the Passions, 15001850, edited by Victoria Kahn, Neil Saccamano, and Daniela Coli, 75-92. Princeton: Princeton University Press.

Daston, Lorraine. 1998. Classical Probability in the Enlightenment. Princeton: Princeton University Press.

Depledge, Emma. 2014. “The Politics of Rape in Nahum Tate's The H istory of King L ear, 1681." In Renaissance Shakespeare: Shakespear eR enaissances, edited 
by Martin Procházka, Michael Dobson, Andreas Höfele, and Hanna Scolnicov, 317-24. Newark: University of Delaware Press.

Deyermond, Alan D. 1975. "The Lost Genre of Medieval Spanish Literature." H ispanic Review 43: 231-59.

Dodd, William. 1999. “Impossible Worlds: What Happens in King Lear, Act 1 , Scene 1." Shakespeare Q uarterly 50 (4): 477-507.

Eagleton, Terry. 1990. Thel deology of the A esthetic. Oxford: Basil Blackwell.

Elias, Norbert. 1978. The Civilizing Process. Vol. 1: The History of M anners. Translated by Edmund Jephcott. N ew York: Urizen Books.

Elton, William R. 1988. King Lear and the Gods. Lexington: University of Kentucky Press.

Empson, William. 1949. "Fool in Lear." The Sewanee R eview 57 (2): 177-214.

Felperin, Howard. 2000. “'This great mirade': Pericles.” In Pericles: Critical Essays, edited by David Skeele, 114-32. New York: Garland.

Fuchs, Barbara. 2004. Romance: A Critical Idiom. New York: Routledge.

Gildon, Charles. 1710. "Remarks on the Plays of Shakespeare." In The W orks of M r. W illiam Shakespear. V olume the Seventh, edited by Nicholas Rowe, 257-444. London; Printed for E. Curll and E. Sanger.

Goldsmith, Oscar James. 1955. Wise Fools in Shakespeare. East Lansing: Michigan State University Press.

Gorer, Geoffrey. 1989. “On Falling in Love.” In Eros, A gapeand Philia: Readings in the Philosophy of Love, edited by Alan Sobel, 6-11. New York: Paragon House.

Green, Lawrence D. 1972. “'Where's my fool?'-Some Consequences of the Omission of theFool in Tate's Lear." Studies in English Literature 12 (2): 25974.

Greenblatt, Stephen. 1980. Renaissance Self-Fashioning: From M ore to Shakespeare. Chicago: University of Chicago Press.

Halpern, Richard. 1991. The Poetics of Primitive Accumulation: English Renaissance Culture and the Genealogy of Capital. Ithaca: Cornell University Press.

Hardman, C. B. 2000. “'Our Drooping Country Now Erects Her Head': Nahum Tate's History of King Lear." The M odern Language Review 95 (4): 913-23.

Hawkes, Terence. 1959. “'Love' in King Lear.” The Review of English Studies 10 (38): 178-81.

Hawkes, Terence, ed. 1995. William Shakespeare, King Lear. Plymouth, U.K.: Northcote House.

Hendricks, Shellee. 1999. "The Curiosity of Nations": King Lear and the Incest Prohibition. PhD diss. McGill University. 
Romack

Herbert of Cherbury, Edward. 1633. D everitate, prout distinguitur a revelatione, a verisimili, a possibili, et a falso. London.

Herbert of Cherbury, Edward. 1645. De causis errorum una cum tractatu de religione laici, et appendice ad sacerdotes. London.

Johnson, Odai. 1995. “Empty Houses: The Suppression of Tate's Richard II." Theatre Journal 47 (4): 503-16.

Johnson, Samuel. 1765. TheW orks of W illiam Shakespeare. Vol. 6. London: J. and R. Tonson et al.

Kahn, Victoria. 2002. "Reinventing Romance, or the Surprising Effects of Sympathy." Renaissance Q uarterly 55 (2): 625-61.

Kermode, Frank. 2005. Shakespeare, Spenser, D onne. London: Routledge.

Lee, Christine S. 2014. "The Meanings of Romance: Rethinking Early Modern Fiction." M odern Philology 112 (2): 287-311.

Lloyd, William Watkiss. 1889. Critical Essays on the Plays of Shakespeare. London: George Bell and Sons.

Massai, Sonia. 2000. "Nahum Tate's Revision of Shakespeare's King Lears." Studies in English Literature 40 (3): 435-50.

May, Simon. 2011. Love: A H istory. New Haven: Yale University Press.

Muldrew, Craig. 1993. "Interpreting the Market: The Ethics of Credit and Community Relations in Early Modern England." Social History 18 (2): 163-83.

Muldrew, Craig. 2001. “'Hard food for Midas': Cash and its Social Value in Early Modern England." Past \& Present 170: 78-120.

Nunn, Trevor. 2016. “Theatre for a New Audience's PERICLES, directed by Trevor N unn." https:/ / www.youtube.com/ watch?v=7N 6RvGMbRQ

Odell, George C. D. (1920) 1966. Shakespeare From Betterton to Irving. Vol. 1. New York: Dover.

Parr, Johnstone 1946. "Edmund's Nativity in King Lear." The Shakespeare A ssociation Bulletin 21 (4): 181-85.

Pascal, Blaise. 1958. Pascal's Pensées with an Introduction by T. S. Eliot. Translated by W. F. Trotter. New York: E.P. Dutton.

Parker, Patricia A. 1979. Inescapable Romance: Studies in the Poetics of a M ode. Princeton: Princeton University Press.

Patay, Douglas Lane. 1984. Probability and Literary Form: Philosophic Theory and Literary Practice in the A ugustan Age. Cambridge: Cambridge University Press.

Rust, Jennifer. 2006. "'Image of Idolatryes': Iconotropy and the Theo-Political Body in The Faerie Q ueene." Religion \& Literature 38 (3): 137-55.

Seiden, Melvin. 1979. "The Fool and Edmund: Kin and Kind." Studies in English Literature 19 (2): 197-214. 
Shakespeare, William. (1608, 1623) 2008. King Lear. In The N orton A nthology of Shakespeare, $9^{\text {th }}$ edition, edited by Stephen Greenblatt et al., 2336-67. N ew York: W.W. Norton.

Sisson, Charles J. 1942. "Shakespeare's Quartos as Prompt Copies. With some Account of Chomley's Players and a N ew Shakespeare Allusion." R eview of English Studies 18 (70): 129-43.

Spencer, Christopher. 1963. "A Word for Tate's King Lear." Studies in English Literature 3 (2): 241-51.

Spinoza, Baruch. 1670.Tractatus theologico-politicus. Hamburg: Henricus Künraht.

Steiner, George. 1968. The D eath of Tragedy. New York: Alfred A. Knopf.

Tate, Nahum. (1681) 1997. The H istory of King Lear. In Shakespeare M ade Fit: Restoration Adaptations of Shakespeare, edited by Sandra Clark, 291-373. London: J. M. Dent.

Tierney-Hynes, Rebecca. 2012. N ovel M inds: P hilosophy and Romance Readers, 1680-1740. New York: Palgrave Macmillan.

Turner, James Grantham. 2012. “'Romance' and the Novel in Restoration England." The Review of English Studies 63 (258): 58-85.

Viator, Timothy J. 1988. "Nahum Tate's Richard II." Theatre N otebook 42 (3): 109-17.

Walsh, John K. 1977. "The Chivalric Dragon: Hagiographic Parallels in Early Spanish Romances." Bulletin of H ispanic Studies (54): 189-98.

Wikander, Matthew H. 1986. "The Spitted Infant: Scenic Emblem and Exclusionist Politics in Restoration Adaptations of Shakespeare." Shakespeare Q uarterly 37 (3): 340-58.

Womack, Peter. 1999. "Shakespeare and the Sea of Stories." The Journal of M edieval and Early M odern Studies 29 (1): 169-87.

Womack, Peter. 2002. "Secularizing King Lear: Shakespeare, Tate, and the Sacred." Shakespeare Survey 55: 96-105.

Wood, Ian. 2006. "Pericles and the Simpsons." Leeds Studies in English 37: 44150.

\footnotetext{
How to cite this article:

Romack, Katherine. “The Romance of Nahum Tate's King Lear." SED ERI 30 (2020): 91-115.

https:/ / doi.org/ 10.34136/ sederi.2020.5

A uthor's contact: kromack@uwf.edu

Postal address: Department of English - University of West Florida -11000 University

Pkwy - Pensacola, FL 32514 - USA 